\title{
"A Period of Consequences": Global Warming Legislation, Cooperative Federalism, and the Fight Between the EPA and the State of California
}

\author{
Krista Yee* \\ TABLE OF CONTENTS
}

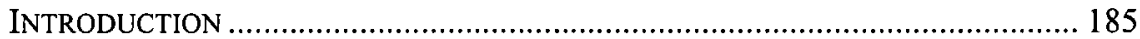

I. IS IT PROPER TO THINK GLOBALLY BUT ACT LOCALLY? ..................... 185

A. Arguments for Federal Control .......................................... 186

B. Importance of State Initiatives .............................................. 187

C. Cooperative Federalism.................................................. 188

II. FEDERAL ENVIRONMENTAL LEGISLATION ...................................... 190

A. Clean Air Act .................................................................. 190

1. Background ................................................................. 191

2. The "California Waiver" .............................................. 191

a. Congressional Intent .............................................. 192

b. Waiver Requirements ............................................... 193

c. State Adoption of California Standards ........................ 195

d. History of California's Waiver Applications ................. 195

B. Energy Policy and Conservation Act of 1975 ........................... 196

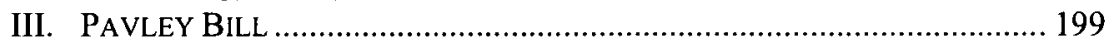

A. Pavley Bill Generally ...................................................... 199

B. Automobile Industry's Response to the Pavley Bill.................. 200

C. California Requests a Waiver Pursuant to CAA ...................... 203

* J.D., Notre Dame Law School, 2008; B.A., English, University of California, Santa Barbara, 2004. I am deeply indebted to Professor Anthony J. Bellia for his invaluable guidance in preparing this article as well as for sparking my interest in the subject. Thanks are also owed to Kameron Cox and Lani Chan for their enduring patience and encouragement; in addition, to the members of Environs for their editorial assistance in preparing this article for publication. Most importantly, I thank my family, particularly my mom for her unconditional love and support.

1 An Inconvenient TRUTH (Lawrence Bender Productions 2006). Al Gore used this phrase in to reference to the increase in global warming over the years. This phrase is originally attributed to Winston Churchill, who did not use it in reference to environmental problems, but rather, referred to wartime concems. 
IV. EPA'S FIRST DENIAL TO CALIFORNIA IN FoRTY YEARS..........................204

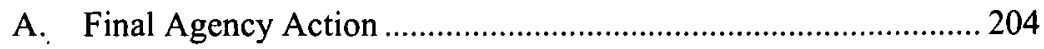

B. Ninth Circuit Petition for Review ............................................ 206

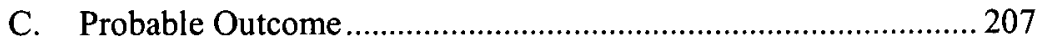

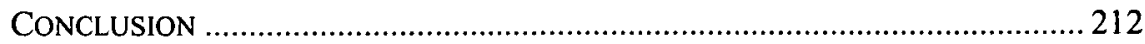




\section{INTRODUCTION}

Average temperatures on Earth have increased steadily over the years due to greenhouse gas emissions in the atmosphere. This climate change, known as global warming, threatens a number of living species - including plants, animals and humans - as glaciers melt, polar ice caps shrink, and sea levels rise. Increased media attention, including $\mathrm{Al}$ Gore's book and film documentary $A n$ Inconvenient Truth, has placed global warming at the forefront of discussion in the United States. Indeed, both the 2008 Republican and Democratic Presidential candidates, John McCain and Barack Obama, committed to reducing greenhouse gas emissions. ${ }^{2}$

Given the serious nature of global warming, local action, rather than purely federal legislation, may be appropriate. In particular, individual states may want to create regulations more stringent than existing federal standards. California, for example, often leads the nation's efforts in solving environmental problems, with global warming as no exception.

Part I of this paper discusses environmental concerns, particularly global warming, and how these concerns implicate federalism. While some advocate for solely national legislation ${ }^{3}$ and others suggest environmental legislation best occurs at state level, ${ }^{4}$ in fact, a hybrid cooperative federalism model best addresses environmental concerns. Part II examines the Clean Air Act ("CAA") as a cooperative federalism model for environmental legislation. ${ }^{5}$ Part II also evaluates whether a later statute, the Energy Policy and Conservation Act ("EPCA"), preempts states from enacting their own legislation pursuant to the CAA. Part III looks at the Pavley Bill, also known as Assembly Bill 1493, one of California's most recent legislative acts requiring a CAA waiver, and explores whether the CAA permits such legislation. Part IV discusses the EPA's denial of California's waiver request for the Pavley Bill and the reasoning behind this historic move. Finally, this paper concludes with a discussion of why the Ninth Circuit should overturn the EPA's decision and how the Pavley Bill exemplifies the most effective form of cooperative federalism.

\section{IS IT Proper to ThINK GLOBALly BUT ACT LOCALLY?}

One of the debates in environmental law concerns whether issues should be addressed at a national or local level. While strong arguments exist on both sides, a cooperative model of federalism that incorporates efforts at the national

2 See, e.g., Juliet Eilperin, Gore Launches Ambitious Climate Advocacy Campaign, WASH. POST, Mar. 31, 2008, available at 2008 WLNR 6042078; Chris Holly, Rowe to Hill: Get Going on Climate Change Bill, 36 ENERGy Daily 29, Feb. 13, 2008, available at 2008 WLNR 5229718.

3 See infra, Part I.A.

4 See infra, Part I.B.

5 Clean Air Act, 42 U.S.C. $\S 7543$ (a) (2006). The Clean Air Act will be discussed in greater detail, infra, Part II.A. 
and local levels will best solve environmental problems.

\section{A. Arguments for Federal Control}

Since environmental problems have far reaching effects on national - in fact, global - concerns, some argue only national legislation can adequately address these issues. Critics of state global warming legislation assert that since some states may be unwilling to enact statutes, particularly costly legislation, only national legislation sufficiently addresses these issues. Furthermore, proponents of a purely federal approach reason that environmental concerns involve issues, such as air and water, not confined to any one state. Finally, proponents argue that efficiency demands federal legislation. ${ }^{6}$

Critics of state-level global warming legislation argue that elements of the environment, such as air and water, do not exist in the exclusive domain of any one state and therefore require national attention. One critic stated that "spillover effects among the states create the strongest justification for federal legislation." Since "pollution knows no boundaries," state legislation would fail to adequately regulate greenhouse gas emissions. ${ }^{8}$ Federal legislation, on the other hand, is "better able to regulate interstate pollution" because it "has a national focus and is a national forum to establish regulations and procedures to resolve interstate conflicts." 9 Essentially, these proponents argue that global problems require large-scale attention on a national and global stage rather than at state or local levels.

As a corollary to the idea that environmental elements affect the whole nation rather than individual states, some critics of state action believe their position is grounded in science. Ultimately, proponents for exclusively federal control argue "only comprehensive, national legislation can deal with environmental systems, which are by their nature systemic."10 In essence, "[w]hen the United States Supreme Court pretends that comprehensive systems can be divided into fragmented and unrelated parts, in the name of federalism, the Court is ignoring simple science." "1

Moreover, proponents of federal environmental legislation assert that some

- See, e.g., Alice Kaswan, The Domestic Response to Global Climate Change: What Role for Federal, State and Litigation Initiatives?, 42 U.S.F. L. REV. 39, 63 (2007).

7 Robert L. Glicksman, From Cooperative to Inoperative Federalism: The Perverse Mutation of Environmental Law and Policy, 41 WAKE FOREST L. REV. 719, 735 (2006) (quoting Richard B. Stewart, Environmental Quality as a National Good in a Federal State, 1997 U. CHI. LEGAL F. 199, 210 (1997)).

8 Id. at 735 (citations omitted).

9 ld.

10 Bruce Ledewitz, The Present and Future of Federalism, 43 DUQ. L. REV. 645, 649 - 50 (2005) ("Scientifically speaking, there is no such thing, for example, as intrastate water. All water has moved across state borders in the past and, of course, will do so again in the future.").

1 Id. 
states are unwilling to enact laws to combat global warming, particularly when they fear costly legislation will provoke the loss of industry. Since a state primarily concerns itself with what happens within its boundaries, "states are likely to under-regulate, since they might regulate only to the extent necessary to address in-state consequences." 12 States do not have the ability to adequately address global warming effects because they would view the transactional costs associated with interstate regulations as too high. ${ }^{13}$ Thus, "federal legislation would allow. states to enjoy environmental protections without fear of losing industry," given that all fifty states would have to comply with the same regulations. ${ }^{14}$

\section{B. Importance of State Initiatives}

Equally strong arguments for encouraging state environmental initiatives exist. For example, some argue states should determine for themselves the amount of environmental protection desired and how to implement these regulations. ${ }^{15}$ When it legislates, a state could potentially establish the proper balance "between environmental protection and economic development."

Furthermore, in response to the claim that global problems require global - or at least national - attention, proponents of local initiatives believe states have the ability to significantly contribute to greenhouse gas reductions. Moreover, the United States government has not been particularly aggressive with global warming legislation. ${ }^{17}$ Thus, states should be able to contribute to the worldwide effort to reduce greenhouse gases when the federal government declines to do so. As one proponent noted, "The global nature of climate change does not denigrate the importance of state efforts," but "as a practical matter ... states should not be held hostage to the United States' unwillingness to engage globally." 18

12 Kaswan, supra note 6, at 6. See also Glicksman, supra note 7, at 735 ("and it seems unlikely that upwind states would ever adequately take into account the concerns of downwind states. The upwind states lack any incentive to cooperate with the downwind states ...").

13 Glicksman, supra note 7, at 735.

14 Kaswan, supra note 6, at $62-63$. ("Scholars argue that the desire to avert the race to the bottom, as demonstrated by the states' failure to control pollution, was a significant factor in the passage of numerous comprehensive federal environmental laws in the 1970s.").

15 See, e.g., id. at 61.

16 Id.

17 See, e.g., id. at 67.

18 Id. See also CBS/AP, U.S. Rejects Mandatory Greenhouse Gas Cuts Despite Scientists' Declaration and Senate Action, U.S. Officials Want No Mandatory Reduction, CBS NEWS, Dec. 6, 2007, available at $\mathrm{http} / / \mathrm{www} . \mathrm{cbsnews.com} / \mathrm{stories} / 2007 / 12 / 06 / \mathrm{tech} / \mathrm{main} 3583099$.shtml (last visited Nov. 20, 2008) ("The United States, participating with nearly 190 nations in a United Nations conference on climate change, is holding firm in its opposition to mandatory cuts in greenhouse gas emissions, despite mounting international and domestic pressure."); Christopher T: Giovinazzo, Comment, California's Global Warming Bill: Will Fuel Economy Preemption Curb California's Air Pollution Leadership?, 30 ECOLOGY L.Q. 893, 899 (2003). 
In addition, the federal government has embraced state action in the field of environmental legislation and policy. When Congress enacts environmental legislation, it often adopts state plans, demonstrating how states effectively serve as laboratories for national legislation. ${ }^{19}$ Other states and the federal government can learn from the successes and failures of varying approaches, incorporating the most successful components into new legislation. When the government limits states to only one federal approach, the United States loses the opportunity to learn from different methods and, arguably, will enact less effective legislation.

\section{Cooperative Federalism}

The environmental legislative regime need not rely solely on either federal or state regulations. To the contrary, cooperative federalism addresses concerns raised by both sides of the federalism debate. Cooperative federalism takes into account the positives and negatives of each regime, integrating federal and state legislation to best serve the environment. Thus, "policy-makers do not have to choose between federal and state approaches; the two can complement one another.,"20

One may broadly describe cooperative federalism as a hybrid system of "federal legislation positing cooperation through interacting state and federal consent." ${ }^{21}$ The Supreme Court recognized cooperative federalism as a system "that rejects, a nationally uniform approach to problem solving in which Congress preempts state authority, and that instead allows state and local authorities to make at least some decisions, subject to minimum federal standards." ${ }^{22}$ Cooperative federalism thus allows states to create regulations to meet their own particular needs subject only to federally mandated minimum standards. $^{23}$

19 See, e.g., Robert B. McKinstry, Jr. and Thomas D. Peterson, The Implications of the New "Old" Federalism in Climate-Change Legislation: How to Function in a Global Marketplace When States Take the Lead, 20 PAC. MCGEorge Global Bus. \& DEV. L.J. 61, 67 (2007) ("By way of example, key provisions of the Clean Air Act were based on California laws regulating air pollution. Many of the strategies incorporated into the Clean Water Act were first worked out by the states comprising the Delaware River Basin Commission. Pennsylvania's efforts to address the problems created by irresponsible mining practices served as the model for the federal Surface Mining Control and Reclamation Act. New Jersey's efforts at hazardous site remediation served as a model for the federal Comprehensive Response, Compensation and Liability Act."); Kaswan, supra note 6, at 71 ("Moreover, the federal government has embraced the state's active role. Rather than perceiving state efforts as a threat to federal power, the federal government has touted state efforts as part of the nation's overall approach to climate change.").

20 Kaswan, supra note 6, at 79.

21 Glicksman, supra note 7, at 725 (quoting Frank R. Strong, Cooperative Federalism, 23 IowA L. REV. 459, 504 (1938)).

22 Id. at 726 (citing City of Rancho Palos Verdes v. Abrams, 544 U.S. 113, 128 (2005) (J. Breyer concurring)).

23 Aside from environmental law, cooperative federalism endeavors have commonly included 
Environmental law in the United States is certainly marked by this hybrid of federal and state legislative interaction: "In fact, almost all of the modern federal environmental laws contemplate a concurrent and significant state role. ${ }^{24}$ In the world of environmental legislation, a federal legislative framework allowing states to enact more stringent regulations allows for greater protection, ultimately leading to more effective contributions toward combating global warming.

Some, particularly those constrained by environmental regulations, may complain that without uniform federal legislation, too many different standards would make compliance extremely difficult. ${ }^{25}$ This problem can be curbed, however, by creating a

modified federalism in which the federal government sets a national standard while one state is allowed to diverge. The remaining states can then choose between the federal or the divergent state standard. While not achieving a uniform standard, industry is nonetheless confronted with only two, instead of ... fifty, standards. ${ }^{26}$

Thus, a successful cooperative federalism system for environmental legislation need not give all fifty states free reign to enact divergent statutes. To the contrary, giving states two or three options may provide sufficient opportunity for experimentation while keeping economic costs down for industries affected by environmental regulations.

Indeed, this type of modified or cooperative federalism has existed in the realm of environmental regulation for the past forty years. Beginning around 1970 , Congress enacted a number of statutes affeeting public health and the environment; almost all these regulations employed some form of cooperative federalism. ${ }^{27}$ For example, Congress enacted the CAA in an attempt to curb air pollution by regulating automobile emissions. ${ }^{28}$ This statute represents a compromise between federal regulations and state standards, creating a minimum federal standard while allowing states to choose the more stringent alternative. $^{29}$

educational programs for disabled children, financial aid for needy families, health insurance programs, financial security for senior citizens, and interstate efforts to fight crime. Id.

24 Kaswan, supra note 6, at 79.

25 For example, the automobile industry must comply with automobile emission regulations. Given that it is easier to ensure compliance with a single industry standard, automobile makers might challenge any system in which multiple standards exist in order to reduce production costs for cars.

26 Kaswan, supra note 6, at 80 (citing Ann Carlson, Federalism, Preemption, and Greenhouse Gas Emissions, 37 U.C. DAVIS L. REV. 281, 313 - 18 (2003)). See also id. at 83 ("If a multiplicity of standards in commerce is a significant concern, some sort of 'modified federalism' may be possible, whereby one or two innovative states, like California, are permitted to set an alternative standard, and other states are given the choice of following the national standards or the California standard.").

27 See, e.g., Glicksman, supra note 7, at 729.

28 See, e.g., Kaswan, supra note 6, at 80.

29 The CAA allows California to request a waiver of preemption provided that California meets 
Through its environmental legislation, Congress created national standards to promote environmental care but "did not completely divest the states and localities from their preexisting regulatory authority ... many of the statutes that Congress adopted during the 1970 s and 1980 s created cooperative partnerships between federal and state governments." ${ }^{30}$ The CAA reflects a commitment to cooperative federalism: although the federal government sets national minimum environmental standards it also allows states "to determine in many contexts the appropriate ways to achieve those goals..., to share the responsibility to enforce state requirements adopted to implement federal regulatory programs, and... to adopt regulatory standards more stringent than the federal government."31

\section{FEDERAL ENVIRONMENTAL LEGISLATION}

As previously noted, Congress responded to environmental problems by enacting legislation largely relying on a system of modified or cooperative federalism. Two of the most prominent pieces of legislation are the CAA, a federal model allowing for state innovation, and the Energy Policy and Conservation Act ("EPCA"), which appears to rely solely on the federal government.

\section{A. Clean Air Act}

Congress first responded to environmental concerns by regulating air pollution with the enactment of the Air Quality Act of $1967 .{ }^{32}$ This statute, which later evolved into the modern CAA, advocated a joint effort between federal and state governments to combat environmental problems. ${ }^{33}$ It stated that "the prevention and control of air pollution at its source is the primary responsibility of States and local governments." ${ }^{\text {"34 }}$ Thus, Congress distributed shared accountability among state and federal governments. Congress "definitively entered the field of regulating air pollution, but did so by adopting a regulatory program dependent upon cooperation between the federal and state governments." 35

certain requirements. This waiver will be discussed in more detail, infra, Part II.A.2.

30 Glicksman, supra note 7, at 728. During this period, Congress also enacted the Clean Water Act, which may also serve as a model for cooperative federalism.

31 Id. at 801.

32 Air Quality Act of 1967, 42 U.S.C. $\$ 7401$ (2006).

33 See Giovinazzo, supra at note 18.

34 Air Quality Act of 1967, 42 U.S.C. § 7401 (2006).

35 Giovinazzo, supra note 18, at 899 ("Through both the AQA and its successor the Clean Air Act, the federal approach to air pollution control has maintained this high degree of dependence on state cooperation, principally through reliance on state adoption and enforcement of State Implementation Plans." (emphasis added)). 


\section{Background}

Congress first codified the modern CAA in 1970 and amended it in 1977 and $19900^{36}$ The CAA regulates a number of factors and toxins associated with air pollution, including: "criteria pollutants,",37 mobile sources, such as motor vehicles, ${ }^{38}$ an air toxics program for hazardous air pollutants, ${ }^{39}$ industrial emissions, particularly those believed to contribute to acid rain, ${ }^{40}$ an Air Emissions Program operated by states under EPA supervision, ${ }^{41}$ and the production and use of chemicals believed to deplete the stratospheric ozone later. $^{42}$

Within these regulated areas, CAA generally preempts states from adopting any conflicting regulations. In particular, and at issue here, CAA largely prohibits states and political subdivisions of states from adopting their own standards for motor vehicle emissions. ${ }^{43}$ Although federal environmental legislation remains dependent on state cooperation, Congress acknowledged the need to avoid multiple auto emissions standards, fearing that such variety "would result in 'increased costs to consumers nationwide, with benefit only to those in one section of the country.",44

\section{The "California Waiver"}

Despite the desire to keep consumer costs low by imposing a uniform automobile emissions standard, Congress did not create a system in which only one federal model could exist. Instead, Congress acknowledged the advantages of a purely federal system, but also realized the need for state autonomy. Thus, Congress created a compromise, embodied by Section 209 of the CAA, allowing California to enact its own regulations provided that the state obtained a waiver of preemption from the EPA. ${ }^{45}$ While generally preempting other states from issuing their own emission standards, Congress gave California "a special waiver in deference to California's 'unique problems and pioneering efforts."

36 The first Clean Air Act was actually enacted in 1963. See Environmental Protection Agency, History of the Clean Air Act, http://epa.gov/air/caa/caa_history.html (last visited Nov. 22, 2008). However, the modern Clean Air Act was based more on the 1970 version than the 1963. As stated previously, the modern Clean Air Act actually has its roots in the Air Quality Act of 1967 rather than the Clean Air Act of 1963. See supra notes 32 and 33.

3742 U.S.C. $\$ 7401$, tit. I (2006). These include particulate matter, sulfur dioxide, carbon monoxide, nitrogen oxides, ozone, and lead.

3842 U.S.C. $\$ 7401$, tit. II (2006).

3942 U.S.C. $\$ 7401$, tit. III (2006).

$40 \quad 42$ U.S.C. $\$ 7401$, tit. IV (2006).

$41 \quad 42$ U.S.C. $\$ 7401$, tit. V (2006).

4242 U.S.C. $\$ 7401$, tit. VI (2006). For example, chlorofluorocarbons.

43 Glicksman, supra note 7, at 783 .

44 Id. at 783-84.

45 Clean Air Act $\S 209,42$ U.S.C. $§ 7543$ (2006); See also Giovinazzo, supra note 18, at 901

46 Giovinazzo, supra note 18 , at 901 (quoting S. REP. No. 403, $90^{\text {th }}$ Cong., $1^{\text {st }}$ Sess. 33 (1967)). 
Once California obtained a waiver for its own emissions regulations, other states could choose to adopt either the federal or California standard. ${ }^{47}$

\section{a. Congressional Intent}

Congress likely chose to create a waiver exception in order to ensure states could still serve as laboratories for vehicle emissions regulation without increasing the cost to consumers. The waiver exception, as enacted by Congress, creates only the potential for two differing standards rather than creating a situation where manufacturers would have to comply with fifty different standards. ${ }^{48}$ Thus, by permitting one state to create a different standard, the CAA allows for greater experimentation in the field of auto emission regulation. Greater experimentation arguably leads to development of more effective regulations. As a result, the successes or failures of one regulation allow lawmakers to change or modify existing rules.

When Congress decided to adopt the CAA's waiver exception, California seemed like an obvious choice due to its unique needs as a large coastal state and its prior innovations in environmental legislation. Congress acknowledged that California confronted "unique problems ... as a result of its climate and topography." ${ }^{, 49}$ Furthermore, California "took steps in the 1960s to control auto emissions even before the federal government did." 50 To avoid obvious favoritism, Congress forbade states from enacting more stringent auto emissions regulations with the exception of "any state which [had] adopted standards... for the control of emissions from new motor vehicle or new motor vehicle engines prior to March 30, 1966." ${ }^{\text {"1 }}$ Being the only state to regulate auto emissions prior to March 30,1966 , California is the only state that can request a

47 See id.

48 Complaint for Declaratory and Injunctive Relief at 50-51, California v. United States Environmental Protection Agency, No. 1:07-cv-02024-RCL (D.C. Cir. Nov. 5, 2007) [hereinafter Complaint for Declaratory and Injunctive Relief]; Giovinazzo, supra note 18, at 901 ("By including the 'California waiver' despite the auto industry's fierce opposition, Congress signaled its desire to encourage California's continued role as a 'laboratory for emission control technology and regulation that could be applied later at the federal level."' In addition, "California's vehicular emission standards are more than just an average example of state action in a field of traditional state power. They are the realization of a very specific Congressional interest in encouraging state experimentation and flexibility. California's emission controls have been successful for both California and the nation at large." $l d$. at 951.)

49 Glicksman, supra note 7, at 784 (citations omitted).

so Id. See also Giovinazzo, supra note 18, at 900 ("Within this cooperative approach to air pollution, no state was more instrumental to the formulation of national air pollution policy than California. Indeed, it was California and the California Air Resources Board whose studies first raised the modern awareness of the sources and impacts of air pollution.").

31 Clean Air Act $\$ 209$ (b)(1), 42 U.S.C. $\$ 7543$ (2006). California was the only state regulating motor vehicle emissions prior to March 30,1966 , and is therefore the only state granted a waiver under the CAA. See also Central Valley Chrysler-Jeep, Inc. v. Goldstene, 529 F.Supp.2d 1151 (E.D. Cal. 2007). 
waiver of preemption from the EPA. ${ }^{52}$ Congress created the form of cooperative federalism embodied in the CAA "to preserve the earlier California innovations in traditional air pollution control mechanisms that provided a model for many of the Clean Air Act's provisions." 53

In addition, Congress intended for California to have the ability to adopt more stringent regulations, thereby allowing the state "to act more quickly than [the EPA] in adopting air pollution control measures." 54 In essence, California does not need to wait for the federal government to acknowledge a problem exists before taking legislative action to try to repair or reduce harms to the coast line or mountain ranges; the state need not sit idly by as environmental problems worsen.

Congress also declared that California should have the "broadest possible discretion in selecting the best means to protect the health of its citizens." ${ }^{.55} \mathrm{By}$ using the phrase "broadest possible discretion," Congress clearly indicated its desire for California to act with innovation and to create new standards with minimal federal interference.' As a result of this special waiver, California has traditionally led the way in creating the nation's automobile emission standards. ${ }^{56}$ In sum, "Congress clearly intended that California, having established itself as having both particular needs with regard to air quality regulation and particular expertise in developing regulations to address its needs, should be empowered to develop alternative and more protective regulations for the control of air pollutants." 57

By amending the CAA, Congress underscored its desire for California to create regulations more stringent than federal standards. The 1977 amendment, for example, required California's standards to be at least as protective as federal standards, but only "in the aggregate." "58 Thus, in evaluating California's standards, the EPA must analyze the proposed regulatory scheme in its entirety, rather than standard-by-standard. ${ }^{59}$ This amendment gives California greater flexibility by allowing the state to devise entirely unique regulations, so long as they, in the aggregate, are ultimately as strong as the national regulations.

\section{b. Waiver Requirements}

Within the text of the CAA, Congress made the requirements for the California waiver explicit: the EPA Administrator must grant California's

32 See Central Valley Chrysler, supra note 51, at 1156.

s3 McKinstry, supra note 19, at 64 .

54 Complaint for Declaratory and Injunctive Relief, supra note 48, at 50 - 51 .

3s Central Valley Chrysler, supra note 51, at 1172 (citation omitted).

s6 Complaint for Declaratory and Injunctive Relief, supra note 48, at 50 - 51.

37 See also Central Valley Chrysler, supra note 51.

58 Clean Air Act $\S 209,42$ U.S.C. $\$ 7543$ (2006); See also Giovinazzo, supra note 18, at 901.

s9 Giovinazzo, supra note 18, at 901 . 
waiver application except in three narrow circumstances. ${ }^{60}$ The language of the statute reads: "The Administrator shall, after notice and opportunity for public hearing, waive application of this section ..." provided that California finds that its proposed standards "will be, in the aggregate, at least as protective of public health and welfare as applicable Federal standards." The word "shall" emphasizes the absence of agency discretion; the EPA is essentially required to grant a waiver, with few exceptions. The Administrator can only deny a request for waiver of preemption under the CAA if he finds: 1) California's determination that its standards are at least as protective as federal standards is arbitrary and capricious; 2) California does not need separate standards to meet .compelling and extraordinary conditions;" or 3) California's standards are inconsistent with CAA section 202(a), which prescribes the standards for motor vehicle air pollution. ${ }^{62}$

Traditionally, both the EPA and courts broadly construe these waiver requirements. As a result, the exceptions to granting a waiver have been interpreted so as to apply only in narrow circumstances. ${ }^{63}$ For example, in determining whether California faces "compelling and extraordinary conditions," the EPA stated these requirements refer only to general conditions within the state. ${ }^{64}$ Such conditions include California's large human and vehicular population, ${ }^{65}$ as well as its unique topography, which encompasses a

60 Clean Air Act $\S 209$ (b)(1), 42 U.S.C. $\S 7543$ (2006) (emphasis added). The focus of this paper is on statutes regulating everyday automobile emissions. Thus, this section exclusively discusses Section 209(b), which governs the waiver exception with regard to regulations for road vehicles. It is worth mentioning, however, that Section 209(e) contains a similar waiver provision for non-road engines or vehicles. This section states, "the Administrator shall, after notice and opportunity for public hearing, authorize Califomia to adopt and enforce standards and other requirements relating to the control of emissions from such vehicles or engines if California determines that California standards will be, in the aggregate, at least as protective of public health and welfare as applicable Federal standards. No such authorization shall be granted if the Administrator finds that (i) the determination of California is arbitrary and capricious, (ii) California does not need such California standards to meet compelling and extraordinary conditions, or (iii) California standards and accompanying enforcement procedures are not consistent with this section." Clean Air Act $\S 209(\mathrm{e})(2), 42$ U.S.C. $\S 7543$ (2006). In addition, states other than California can adopt these standards "if (1) such standards and implementation and enforcement are identical, for the period concerned, to the California standards authorized by the Administrator under subparagraph (A), and (ii) California and such State adopt such standards at least 2 years before commencement of the period for which the standards take effect." Clean Air Act $\S 209(\mathrm{e})(2)(B), 42$ U.S.C. $\$ 7543$ (2006); see also Giovinazzo, supra note 18, at 902 ("The CAA also encourages California's innovation and flexibility by including a nearly identical California waiver to preemption of state emissions standards for non-road vehicles and by allowing California to pass its own fuel additive requirements without EPA approval.")

61 Id.

62 Clean Air Act $\S 202(a), 42$ U.S.C. $\S 7521$ (2006). This provision requires that regulations take into account the most feasible standards given the technology available at the time.

63 See e.g., Giovinazzo, supra note 18, at 903 (citation omitted).

64 Id.

65 Today, California is the most populous state in the nation, home to one in seven Americans. Its population currently approaches thirty-seven million and is projected to reach forty-four million 
large coastline, mountain range, and forest area highly susceptible to wildfire. ${ }^{66}$ In addition, the South Coast and San Joaquin regions of California "experience the highest ozone concentrations in the United States; they have the only severe and serious health designations for the national 8-hour ozone standard. Global warming increases the formation of ozone." Such conditions make "it almost impossible to refute that" California will always have "compelling and extraordinary conditions" when it applies for a waiver. ${ }^{68}$ California's uniquely diverse topography and high population are unlikely to change in the future. Therefore, the state should certainly continue to meet the "compelling and extraordinary conditions" requirement as the EPA and courts construe the phrase.

\section{c. State Adoption of California Standards}

Initially, Congress did not permit any state other than California to deviate from federal regulation of auto emissions. However, Congress significantly amended the CAA in 1977 to allow states the choice of adopting the national standard or emission regulations identical to California's. ${ }^{69}$ Currently, pursuant to Section 209(b)(3) of the CAA, other states may not request waivers of preemption to create their own standards, but they may adopt California's, provided the regulations received a waiver of preemption. ${ }^{70}$ States that follow the California standards enacted pursuant to a grant of waiver are deemed to be in compliance with the national standards. ${ }^{71}$

\section{d. History of California's Waiver Applications}

Historically, the EPA has granted California's waiver requests whenever the proposed standards meet minimum federal standards. During the forty years between the enactment of the CAA in 1967 and most of 2007, the EPA

by the year 2020 and sixty million people by 2050 . Complaint for Declaratory and Injunctive Relief, supra note 48 , at $23-24$. This high population has led to greater ozone concentrations in California than in other states. See http://ag.ca.gov/globalwarming/pdf/Summary_of_AG_Testimony_011008.pdf.

66 Office of the Attorney General, State of California, Global Warming Impacts in California http://ag.ca.gov/ globalwarming/impact.php (last visited Nov. 20, 2008).

67 Complaint for Declaratory and Injunctive Relief, supra note 48, at 35.

68 See Giovinazzo, supra note 18 , at 903.

69 Clean Air Act $\S 209$ (b)(3), 42 U.S.C. $§ 7543$ (2006); See Glicksman supra note 7, at 784.

70 Clean Air Act $\S 177,42$ U.S.C. $\$ 7507$ (2006). Clean Air Act $\S 209$ (b)(3), 42 U.S.C. $§ 7543$ (2006) ("In the case of any new motor vehicle or new motor vehicle engine to which state standards apply pursuant to a waiver granted under paragraph (1), compliance with such State standards shall be treated as compliance with applicable Federal Standards for purposes of this title."). See also Central Valley Chrysler-Jeep, Inc. v. Goldstene, 529 F.Supp.2d 1151 (E.D. Cal. 2007).

"I See, e.g., Central Valley Chrysler, 529 F.Supp.2d at 1173 . They are deemed to be in compliance under Section 209(b)(3) 42 U.S.C. $§ 7543$. 
consistently approved California's waiver requests. ${ }^{72}$ Indeed, prior to the Pavley Bill, California's requests for preemption waivers under the CAA were always at least partially granted by the EPA. ${ }^{73}$

As a result of EPA's liberal approval of the California waiver, other states as well as the federal government have benefited from California's successes in environmental legislation. California legislation, enacted pursuant to Section 209 of CAA, has been largely popular as evidenced by the numerous states adopting these regulations. ${ }^{74}$ Moreover, the federal government "repeatedly draws from California's playbook in adopting its own emission standards." 75 From banning lead in gasoline to creating clean vehicle standards, Congress has repeatedly taken advantage of California's innovations, signaling its continued support for the California waiver. ${ }^{76}$

\section{B. Energy Policy and Conservation Act of 1975}

After the enactment of the CAA, Congress continued to legislate on environmental issues. For example, the Energy Policy and Conservation Act of 1975 (EPCA) attempts to broadly meet the nation's energy demands and encourages conservation wherever feasible. ${ }^{77}$ Unlike the CAA, however, EPCA did not include a provision for addressing California's needs for preemption waivers. The absence of a waiver provision resulted in some uncertainty as to whether California regulations under the CAA that related to energy conservation could be preempted by the EPCA.

72 James E. McCarthy and Robert Meltz, California's Waiver Request to Control Greenhouse Gases Under the Clean Air Act, CRS REPORT FOR CONGRESS, Oct. 1, 2007, at 11 - 12 (" . . one might say that there have been at least 95 waiver requests, but nearly half of these were relatively minor actions that may not deserve to be counted as formal requests. Of these, all were granted in whole or in part. 'I don't think we've ever outright denied a request,' according to an OTAQ official; 'but there were some grants in which we denied part or delayed the effective date of part on feasibility grounds,' he added."). See also California Attorney General, News and Alerts: "Brown Blasts EPA for Betraying Public Trust," http://ag.ca.gov/newsalerts/release.php?id=1516, Jan. 10, 2008 (last visited Nov. 20, 2008); Giovinazzo, supra note 18, at 903 ("In practice, California's waiver applications are almost always approved."); Kaswan, supra note 6, at 50 ("EPA has virtually always granted California's waiver requests ...").

73 See supra note 72.

74 See, e.g., Glicksman, supra note 7, at 784 ("In 1977, Congress amended the CAA to allow other states to adopt and enforce motor vehicle emissions controls that are identical to any California standards for which EPA has already granted a waiver. Several states, particularly in the northeast, have taken advantage of this provision by adopting standards'equivalent to the more stringent California standards approved by EPA.").

7s Giovinazzo, supra note 18, at 951 ("When California required catalytic converters, a few years later their effectiveness was clear and the federal govemment required them as well. When California banned lead in gasoline, the federal government followed suit. When California adopted a groundbreaking clean vehicles program, the federal government followed, explicitly adopting CARB's standards and initiating a clean-vehicles program-in California.").

76 Id. and accompanying text.

77 See Energy Policy and Conservation Act, 42 U.S.C. $\$ 6201$ (2006). 
Congress' stated purpose for the EPCA includes, for example, regulating certain energy uses and creating energy conservation programs, ${ }^{78}$ conserving water ${ }^{79}$ and improving the energy efficiency of certain consumer products such as motor vehicles. ${ }^{80}$ In order to improve the energy efficiency of automobiles, Congress imposed strict new fuel efficiency requirements known as the Corporate Average Fuel Economy ("CAFÉ") standards. ${ }^{81}$ The EPCA also contained a broad preemption clause, which, unlike the CAA, did not provide California with a waiver exception. The EPCA expressly says states "may not adopt or enforce a law or regulation related to fuel economy standards.

Despite the broad preemption clause and lack of waiver exception, the EPCA does not affect California regulations enacted pursuant to Section 209 of the CAA. In other words, California may still establish its own standards under the CAA without violating the EPCA. If the EPCA did, in fact, preempt California's CAA regulations, the EPCA would effectively bar the state from passing emission standards different from the federal standards. ${ }^{83}$ However, in passing the EPCA, Congress had no intention of limiting California's flexibility under the CAA. ${ }^{84}$

While EPCA does contain a broad preemption provision, applying it literally would preempt a variety of state laws and lead to absurd results surely not intended by Congress. Putting aside the California waiver under the CAA, a literal application of the EPCA preemption provision would preempt states from setting speed limits ${ }^{85}$ or imposing gasoline taxes, ${ }^{86}$ since these acts "relate" to fuel economy. However, it seems illogical that Congress would use EPCA to prevent states from creating their own speed limits or taxing fuel. ${ }^{87}$ Reading EPCA to preempt California from enacting legislation related to fuel economy

7842 U.S.C. $\S 6201(4)(2006)$.

7942 U.S.C. $\S 6201(8)(2006)$.

8042 U.S.C. $\$ 6201(5)(2006)$.

8142 U.S.C. $\S 7543$ (a) (2006). These standards set the minimum average fuel miles-per-gallon for all trucks and cars in a manufacturer's fleet by model year. Because these standards only apply to the average of a manufacturer's fleet, the CAFE standards "encouraged carmakers to sell lots of small fuel-efficient vehicles at sometimes unprofitable prices, so they could keep selling their more profitable gas guzzlers." Karen Lundegaard, Crash Course: How the U.S. Shifted Gears to Find Small Cars Can be Safe Too; Studies Discover Size, Quality Are as Important as Weight; Drafting Rules for SUV's; Honda Sticks Up for Little Guy, WALL ST. J., Sept. 26, 2005, at Al.

82 Energy Policy and Conservation Act, 49 U.S.C. $\$ 32919$ (a) (2006).

83 Giovinazzo, supra note 18 , at 893 .

${ }^{84}$ See, e.g., id. at 897 ("Congress never meant EPCA to limit California's autonomy.").

85 Id. at $897 \&$ n. 240 ("For a variety of technical reasons, a vehicle driven faster than about forty-five miles per hour over a given distance is progressively less efficient-i.e. burns more gasoline-than a car driven slower over the same distances. Thus, lowering highway speed limits increases vehicular fuel economy." (citing U.S. Dep't of Transp., Think Fast, available at http://www.nhtsa.dot.gov/people/outreach/safesobr/pub/think.pdf)).

${ }_{86}$ By imposing a tax on gasoline, consumers may be more conservative with automobile use, leading them to give more consideration to fuel economy when purchasing a car.

87 Giovinazzo, supra note 18, at 933. 
would also conflict with what Congress intended to accomplish under CAA. ${ }^{88}$ Thus, the preemption provision contained in the EPCA should not be read as broadly as the plain language suggests.

Congress also demonstrated the intent for California to continue using its CAA waivers, notwithstanding the EPCA. Congress understood California CAA regulations "as a category of federal emissions standards. For legal purposes, then, California's emissions regulations are federal regulations, and the EPCA's preemption clause does not reach them at all." 89 Additionally, the EPCA originally recognized California's CAA waiver by defining "federal standards" to include "emission standards applicable by reason of section 209(b)" of the CAA. ${ }^{90}$ Thus, when Congress enacted EPCA, it accounted for regulations enacted pursuant to the California waiver by giving these standards the same status as federally enacted regulations.

Furthermore, in evaluating both the EPCA and the CAA, courts have held the two statutes are not at odds with each other; instead, courts equate California regulations enacted under the CAA waiver provision with federal standards. One court concluded the California standards enacted under a preemption waiver become "federalized," thereby eliminating the concern for state versus federal regulations under the EPCA. ${ }^{91}$ The court noted that "when EPCA was passed, Congress unequivocally stated that federal standards included EPAapproved California emissions standards. ${ }^{.92}$ Alternatively, courts have also held that, even if California standards are not "federalized," still no preemption problem exists:

This court again declines to cast the issue as being one of 'federalization' of the proposed California standards. Rather, the court refers to its discussion on EPCA preemption in which it determined that there is no indication of congressional intent that a proposed California state regulation granted waiver of preemption under section 209 of the Clean Air Act is different for any purpose from a regulation that is promulgated directly by EPA. ${ }^{93}$

Thus, whether or not California standards are "federalized," remains largely irrelevant; it is enough to say these regulations should be treated the same as

88 See, e.g., Giovinazzo, supra note 18, at 893 (“Constricting California's autonomy would directly conflict with Congress' intent and would impede the kind of state innovation that should be favored by an administration and a Supreme Court friendly to federalism.").

89 Id. at $948-49$.

90 Pub. L. No. 94-163 § 502(d)(3)(D)(i-ii), 89 Stat. 901,905 (1975). Note, however, that when the EPCA was reauthorized in 1994, this language was deleted. H.R. REP. No. 103-180 at 584 (1994).

91 Central Valley Chrysler-Jeep, Inc. v. Goldstene, 529 F.Supp.2d 1151, 1164 (E.D. Cal. 2007) (citation omitted).

92 Id. at $1173($ citing $\S 502(\mathrm{~d})(3)(\mathrm{D})(\mathrm{i}))$.

93 Id. at 1182 . 
those promulgated by the EPA. Due to the fact that California regulations are treated like federal standards, legislation enacted pursuant to the California waiver does not conflict with the EPCA.

In addition, because the CAA waiver provision accounts for California's preCAA/EPCA automobile pollution regulations, "the court must presume that Congress did not intend that EPCA would supersede California's exercise of its historically established police powers." ${ }^{, 94}$ The Supreme Court has made clear that EPA regulations, as well as those enacted by California pursuant to CAA waiver, "that control carbon dioxide emissions serve a purpose that is distinct from, and not in conflict with, the purpose of the EPCA." and EPCA promote a cleaner environment by, at least in part, governing automobile emissions, they ultimately serve distinct and separate purposes. These purposes, while complimentary, do not overlap to an extent that would create conflict between the two. Thus, California legislation enacted pursuant to CAA waiver does not conflict with EPCA and is therefore not preempted.

\section{PAVLey BILL}

California has taken advantage of Section 209 of CAA on numerous occasions, with the EPA always granting California's petition for waiver. These waiver requests often face strong opposition as the automobile industry fights to dissuade other states looking to adopt California's tough new standards. Recently, California generated even more attention when the EPA flat out denied the state's waiver request for the first time in the history of CAA.

\section{A. Pavley Bill Generally}

On July 22, 2002, former California Governor Grey Davis signed Assembly Bill 1493 into law, requiring automobile companies to reduce vehicular greenhouse gas emissions. ${ }^{96}$ Given that automobile emissions account for twenty percent of the nation's greenhouse gas emissions, ${ }^{97}$ California has deemed it necessary to curb the harmful effects of tailpipe exhaust. Tailpipe emissions present an even lärger problem for California, amounting to over thirty percent of the state's greenhouse gas emissions. ${ }^{98}$ More commonly known as the Pavley Bill, ${ }^{99}$ the statute authorizes the California Air Resource Board ("CARB") to regulate greenhouse gases as part of the California Motor Vehicle Program and was the first law to address greenhouse gases emitted by auto

94 Id. at $1174-75$.

95 Id. at 1175.

96 CAL. Health \& SAFETy CODE $\$ 43018.5$ (West 2006).

97 Kaswan, supra note 6, at 48.

98 Id.

99 Named for Califomia Assemblywoman Fran Pavley (Dem.) who, on behalf of the environmental group Bluewater Network, authored the bill. See, e.g., id. 
exhaust.

Under the Pavley Bill, the California legislature directed CARB to develop "regulations that achieve the maximum feasible and cost-effective reduction of greenhouse gas emissions from motor vehicles." 100 In response, CARB adopted standards designed to curb tailpipe emissions in September $2004 .^{101}$ These aggressive standards gave the automobile industry until the 2009 model-year to produce a new California breed of motor vehicles that, collectively, would result in a twenty-two percent emissions reduction by 2012 and a thirty percent reduction by $2016 .{ }^{102}$

Notably, the Pavley Bill was the "first (and only) regulatory effort in the nation to address the automobile sector's greenhouse gas emissions."103 If granted a preemption waiver, the bill has the potential to influence tailpipe emissions throughout the nation since other states may adopt California standards. Already adopted by fourteen other states, ${ }^{104}$ the Pavley Bill clearly set a standard favored by roughly forty percent of the national population. ${ }^{105}$ In fact, these states began implementing the Pavley Bill standards even prior to the EPA's decision on California's waiver request. ${ }^{106}$

\section{B. Automobile Industry's Response to the Pavley Bill}

Global warming legislation often impacts the automobile industry, forcing manufacturers to create new cars in compliance with recently enacted environmental standards, sometimes at great cost. ${ }^{107}$ Thus, from a business perspective, it is natural for the automobile industry to resist new environmental legislation. As expected, the automobile manufacturers promptly brought suit

100 CAL. Health \& SafeTy CODE $\S 43018.5$ (West 2006).

101 Kaswan, supra note 6, at 49.

102 Democratic Energy, Automobile $\mathrm{C02}$ Emissions Rule-California, http://www.newrules.org/environment/ climateca.html (last visited Nov. 20, 2008).

103 Kaswan, supra note 6, at 48. See also J.R. DeShazo and Jody Freeman, Timing and Form of Federal Regulation: The Case of Climate Change, 155 U. PA. L. REv. 1499, 1526 - 27 (2007).

104 Califomia Attomey General, News and Alerts: "Brown Blasts EPA for Betraying Public Trust," available at http://ag.ca.gov/newsalerts/release.php?id=1516, Jan. 10, 2008. These states include: Arizona, Connecticut, Florida, Maine, Maryland, Massachusetts, New Jersey, New Mexico, New York, Oregon, Pennsylvania, Rhode Island, Vermont and Washington. Four other states, Colorado, Delaware, Illinois and Utah are in the process of adopting the Pavley Bill standards.

105 See Environmental Defense Fund, States Take Action on Climate: Regional and State Agreements to Limit Emissions (Sep. 13, 2007), available at http://www.edf.org/article.cfm?contentid=4889 (last visited Nov. 20, 2008).

106 DeShazo, supra note 103, at 1521 - 22.

107 Due to these costs, the automobile industry has vigorously fought any deviation from a single, unified national standard. Having lost the fight over allowing California to create its own standards, automobile companies tumed instead to other states and "have consistently sought to block other states from adopting standards that are not 'identical to Califormia's, on the ground that disparate standards would force the automakers to produce a 'third car' in addition to the two (one federal, one Californian) that the Act already permits." DeShazo, supra note 103, at 1513. 
after Governor Davis signed the Pavley Bill into law.

The Alliance of Automobile Manufacturers, Association of International Automobile Manufacturers, and a number of California automobile dealers filed a federal lawsuit arguing that California lacks the authority to regulate tailpipe greenhouse gas emissions. ${ }^{108}$ The lawsuit claimed EPCA preempts any state, even California, from regulating greenhouse gas emissions from automobiles. ${ }^{109}$ In support, the industry observed that any regulation would require manufacturers to significantly improve fuel efficiency, as carbon dioxide in tailpipe emissions are a byproduct of fuel economy. ${ }^{110}$ Furthermore, the automobile industry argued that the federal government has the sole authority to regulate fuel economy and federal law therefore preempts the Pavley Bill. ${ }^{111}$ Finally, the automobile industry argued, foreign policy considerations prevent California from enacting global warming legislation. ${ }^{12}$

The District Court for the Eastern District of California ultimately rejected the automobile industry's claims. First, the court found that EPCA did not expressly preempt California from creating legislation like the Pavley Bill. The court noted the "preemptive force of [EPCA] extends very narrowly." "113 Thus, legislation enacted pursuant to the California waiver is not preempted, despite greatly affecting fuel economy, "where the required increase in fuel economy is incidental to the state law's purpose of assuring protection of public health and welfare under the Clean Air Act."114 It follows, therefore, that as long as California's primary purpose behind global warming legislation is to promote the public health and welfare rather than to regulate fuel economy, courts will not read the EPCA to preempt these regulations.

Furthermore, the court found no conflict preemption between EPCA and the Pavley Bill. Since this legislation would "fulfill both EPA's objective of 'greatest degree of emission reduction achievable through the application of technology ... and EPCA's objective of implementing the 'maximum feasible average fuel economy' standards," the Pavley Bill can coexist with the EPCA. ${ }^{115}$ The Pavley Bill, in fact, furthers EPCA by promoting more efficient fuel

108 See Central Valley Chrysler-Jeep, Inc. v. Goldstene, 529 F.Supp.2d 1151 (E.D. Cal. 2007). See also DeShazo, supra note 103, at 1513 ("Having lost the battle to prevent California from retaining the power to exceed federal standards, the auto industry sought to limit any remaining potential for disparate state regulation. To do this the industry has appealed not to Congress but to the courts ...").

109 Central Valley Chrysler, 529 F.Supp.2d at $1164-65$.

110 Id. at $1157-58$.

111 Id. at 1165 .

112 Id. In response, Califomia argued the Pavley Bill does not focus on fuel economy, but, rather, on tailpipe emissions which are clearly within its regulatory authority. See DeShazo, supra note 103 .

113 Central Valley Chrysler, 529 F.Supp.2d at 1176

114 Id.

115 Id. at 1179 . 
economy standards. Finding no express or conflict preemption, the court then turned to the automobile industry's foreign policy preemption claim.

The district court rejected the argument that the Pavley Bill conflicts with foreign policy. Since the automobile industry failed to identify any foreign policy with which the Pavley Bill conflicted, the court found no foreign policy preemption; the automakers could only show the United States had a general policy to try to reduce greenhouse gases by negotiating agreements with other nations. ${ }^{116}$ Since the Pavley Bill seeks to regulate only automobile standards for cars sold within California's borders, it only affects the state's market. As such, the Pavley Bill does not interfere with any federal policy of reducing greenhouse gas emissions through agreements with foreign nations. ${ }^{17}$ In fact, the court determined the Pavley Bill's standards "are ... supportive of the United States' policy because they provide market-based incentives for exactly the sorts of innovation envisioned by the G8 Summit Report." 118

The Supreme Court has also agreed that regulation of greenhouse gases by a state does not impair negotiations with foreign nations to generally reduce greenhouse emissions. ${ }^{119}$ The Court acknowledged the broad authority possessed by the President in the field of foreign policy, but noted that such "authority does not extend to the refusal to extend domestic laws." 120 While the President can negotiate agreements with foreign nations to reduce greenhouse gases, he does not have exclusive control over global warming legislation. Thus, California's attempt to exercise the waiver provision of CAA does not conflict with foreign policy and is therefore not preempted.

Rejecting the argument that EPCA preempts the Pavley Bill - including express, conflict and foreign policy preemption - the court essentially suggests that nothing should prevent California from enforcing the Pavley Bill. Although the Central Valley Chrysler court did not address the question of whether the EPA should grant California's waiver request, given that the EPCA does not preempt the proposed regulations and the EPA has historically granted all of California's requests under CAA, it would seem that the state's request should certainly be granted in this case.

116 Id. at $1183-89$. The court noted that in order for the plaintiffs in this case to adequately show foreign policy preemption, they must be able to "show what the policy of the United States is and precisely how California's AB 1493 Regulations (Pavley Bill), if granted waiver of preemption by EPA and implemented, would interfere with the United States' foreign policy."

117 Id.

118 Id.

119 Mass. v. E.P.A., 127 S.Ct. 1438, 1463 (2007). In this case, the EPA claimed that it did not have the authority to regulate greenhouse gas emissions because "regulating greenhouse gases might impair the President's ability to negotiate with 'key developing nations' to reduce emissions."

120 Kaswan, supra note 6, at 52 (citing Mass. v. E.P.A., supra). 


\section{California Requests a Waiver Pursuant to CAA}

After enacting the Pavley Bill, California requested a waiver from the EPA under the CAA. ${ }^{121}$ The regulations set forth by CARB cannot be implemented until the EPA grants a waiver from CAA's preemption provision. As discussed above, the EPA must grant California's waiver request provided the state's proposed standards are at least protective as federal standards, California faces "compelling and extraordinary conditions," and the EPA Administrator does not find California to be acting in an arbitrary and capricious manner. ${ }^{122}$ The Pavley Bill certainly meets the requirements for a grant of waiver.

The Pavley Bill is the first legislation of its kind; the federal government had not yet enacted any regulations governing greenhouse gas emissions from automobile tailpipes. Thus, the Pavley Bill could not be found to be less protective than any non-existent federal standards. Second, California certainly faces "compelling and extraordinary conditions" as the term is interpreted by courts. Finally, California's determination that its standards are, in the aggregate, at least as stringent as federal standards and that the state has a reason for enacting its own regulations should not be deemed "arbitrary and capricious."

Furthermore, as discussed above, EPCA does not preempt the Pavley Bill. Although the Pavley Bill affects fuel economy, its primary purpose is to regulate greenhouse gases and reduce global warming. ${ }^{123}$ Due to the fact that the Pavley Bill meets all the requirements for the California waiver and is not preempted by the EPCA, the EPA has no reason to deny the state's request for waiver under CAA.

Nonetheless, the EPA initially refused California's waiver request on the ground that the agency believed it did not have authority to regulate greenhouse gases. In August 2003, the EPA signed a notice denying a petition to regulate greenhouse gas emissions from motor vehicles under CAA claiming "Congress has not granted EPA authority under the Clean Air Act to regulate [carbon dioxide] and other greenhouse gases for climate change purposes."124

121 Complaint for Declaratory and Injunctive Relief, supra note 48, at 16.

122 Clean Air Act § 209(b), 42 U.S.C. § 7543(b) (2006).

123 See, e.g., David R. Hodas, State Law Responses to Global Warming: Is it Constitutional to Think Globally and Act Locally?, 21 PACE ENVTL. L. REV. 53, 74 - 75 (2003) ("Thus, to the extent that a particular state GHG statute is deemed to regulate motor vehicle emissions in a manner inconsistent with the California car preemption waiver it might conflict with the Clean Air Act's two car mandate. For instance, California has recently enacted a statute limiting future greenhouse gas emissions, which might be deemed an effort to regulate motor vehicle emissions beyond what EPA currently allows under its approved versions of the California car. However, should California petition EPA to approve a new version of the California car, which incorporates reduced carbon dioxide emissions, EPA might be obligated to approve the application thereby waiving any Clean Air Act preemption" (emphasis added)).

124 Richard Black, U.S. Government "Must Restrict CO2",BBC News, Apr. 9, 2005, available at http://news.bbc.co.uk/1/hi/sci/tech/4424867.stm The agency further "determined that setting 
The Supreme Court disagreed with the EPA's contentions, however, and found greenhouse gas emissions to be squarely within the purview of the agency. ${ }^{125}$ The Court held that Congress had empowered the EPA to enact controls on greenhouse gases under CAA, even if such regulations might affect fuel efficiency. ${ }^{126}$ Furthermore, the CAA specifically directs the EPA to protect the public health; thus, the EPA has a duty to regulate greenhouse gas emissions that threaten public welfare. ${ }^{127}$ This duty exists regardless of the effect such regulations may have on fuel efficiency. ${ }^{128}$

The Court also found the EPA possessed a broad regulatory authority because Congress intended for the EPA to be able to respond to threats not known or envisioned at the time CAA was drafted: "The broad language of $\S 202(a)(1)$ reflects an intentional effort to confer the flexibility necessary" to meet unforeseen regulatory needs. ${ }^{129}$ Even though Congress may not have considered climate-change legislation when it drafted the CAA, this fact does not preclude the EPA from regulating greenhouse gas emissions. The EPA should adapt and evolve with the scientific community's understanding of environmental hazards and regulate these dangers as Congress intended.

\section{EPA'S FIRST DENIAL TO CALIFORNIA IN FORTY YEARS}

After the Supreme Court held, in Massachusetts v. E.P.A., that the EPA has authority to regulate greenhouse gas emissions, California renewed its request for waiver under CAA so it could implement the standards created in the Pavley Bill.

\section{A. Final Agency Action}

In a final agency action issued at the end of 2007, the EPA denied California's request for a preemption waiver for the Pavley Bill. The EPA reasoned that because greenhouse gases have effects far beyond the borders of California, only national legislation and global agreements can satisfactorily address global warming issues. ${ }^{130}$ It distinguished the waiver request for the Pavley Bill from previous waivers because:

GHG emission standards for motor vehicles is not appropriate at this time."

125 Mass. v. E.P.A. 127 S.Ct. at 1455 - 56 (2007).

126 Id.

$127 \mathrm{Id}$.

128 Id.

129 Id. at 1462 (Furthermore, the court expressly noted that "While the Congresses that drafted $\S$ 202(a)(1) might not have appreciated the possibility that buming fossil fuels could lead to global warming, they did understand that without regulatory flexibility, changing circumstances and scientific developments would soon render the Clean Air Act obsolete" and therefore crafted the statute to avoid such obsolescence.).

130 See Letter from EPA Administrator Johnson to Governor Schwarzenegger (Dec. 19, 2007) available at http://ag.ca.gov/cms_attachments/press/pdfs/n1514_epa-letter.pdf. 
[u]nlike other air pollutants covered by previous waivers, greenhouse gases are fundamentally global in nature. Greenhouse gases contribute to the problem of global climate change, a problem that poses challenges for the entire nation and indeed the world. Unlike pollutants covered by other waivers, greenhouse gas emissions harm the environment in California and elsewhere, regardless of where the emissions occur. In other words, this challenge is not exclusive or unique to California and differs in a basic way from the previous and regional air pollution problems discussed in prior waivers. $^{131}$

Ignoring the fact that California has some of the worst pollution and air quality in the nation, the EPA found that greenhouse gas emissions within the state contribute to global environmental problems. Thus, the Administrator of the EPA, Stephen Johnson, reasoned that since global warming problems extend beyond California, "so too must ... the solution." 132 Furthermore, because greenhouse gas emissions affect people worldwide, the Administrator refused to accept California's argument that it faced "compelling and extraordinary conditions" and therefore denied the waiver. ${ }^{133}$

In addition, when Administrator Johnson denied the waiver request, he stated that California did not need the Pavley Bill because of the Energy Independence and Security Act of 2007 ("EISA"), which President Bush had signed into law earlier that day. ${ }^{134}$ According to the Administrator, the Pavley Bill was not needed because the EISA tightened fuel economy standards for automobiles under EPCA. Administrator Johnson ignored the fact that California petitioned for waiver more than two years prior to the enactment of the EISA, and refused to recognize that the Pavley Bill would go into effect sooner than federal requirements. ${ }^{135}$ Instead, without citing any supporting findings, the Administrator asserted the EISA would impose tougher requirements than any state legislation.

$131 \quad I d$.

132 Id

133 Id. "In light of the global nature of the problem of climate change, I have found that California does not have a 'need to meet compelling and extraordinary conditions.' Accordingly, I have decided that EPA will be denying the waiver . . " See also Notice of Decision Denying a Waiver of Clean Air Act Preemption, 73 Fed. Reg. 12156 (Mar. 6, 2008) ("I have concluded that section 209(b) was intended to allow California to promulgate state standards applicable to emissions from new motor vehicles to address pollution problems that are local or regional. I do not believe section $209(\mathrm{~b})(1)(B)$ was intended to allow California to promulgate state standards for emissions from new motor vehicles designed to address global climate change problems; nor, in the alternative, do I believe that the effects of climate change in California are compelling and extraordinary compared to the effects in the rest of the country.").

134 California Disputes EPA Claims Over Energy Laws GHG Reductions, 19 CLEAN AIR REPORT 1, Jan. 10, 2008, available at 2008 WLNR 464957.

135 Id. ("CARB and other state officials were 'stunned' to hear Johnson's estimate, 'because California's standards go into effect earlier, take effect faster and are more aggressive, and at the endpoint, they're more stringent."). 


\section{B. Ninth Circuit Petition for Review}

California promptly responded to the EPA decision: on the first business day of 2008, officials filed suit in the Ninth Circuit Court of Appeals, asking the court to overturn the EPA's rejection of the state waiver request. ${ }^{136}$ The complaint attacked the EPA's decision on the ground that the agency did not make a finding of "nationwide scope or effect" of the Pavley Bill as required by the Clean Air Act. ${ }^{137}$ As of early September 2008, the Ninth Circuit has yet to issue a decision.

California further alleged that its extraordinary and compelling needs entitled it to a waiver under the CAA. In addition to the general conditions of California discussed in Part II.A.2, supra, California claimed a compelling need because motor vehicle emissions contribute so heavily to greenhouse gases. ${ }^{138}$ The effects of greenhouse gas emissions from automobiles disproportionately impacts California: the state has over thirty-two million registered vehicles, twice the number in any other state. ${ }^{139}$ Not only do automobiles account for thirty percent of greenhouse gas emissions in California, but they are the most rapidly growing source of greenhouse gas. ${ }^{140}$ As a result, "the longer the delay in reducing these emissions, the more costly and harmful will be the impact on California.,"141

In addition to the state's compelling need for the Pavley Bill, California noted the EISA, enacted under the EPCA, did not affect the state's ability to apply for a waiver under CAA. In appealing EPA's ruling, California noted,

We are aware that Congress has enacted the Energy Independence and Security Act of 2007 . . But changes to EPCA do not affect EPA's authority or duties under Section 202 of the Clean Air Act... As the Supreme Court has emphasized, EPA's statutory obligation to promote public health and welfare is "wholly independent' from EPCA's 'mandate to promote energy efficiency.",142

Furthermore, when it enacted EISA, Congress stated outright that it did not

136 Id.

137 Petition for Review, California v. E.P.A. (9th Cir. Jan. 2, 2008) (citing Clean Air Act $\S$ 307(b)(1), $42 \quad$ U.S.C. $\quad \S \quad 7607), \quad$ available http://ag.ca.gov/cms_attachments/press/pdfs/n1514_epapetition-1.pdf. The petition for review also contained California's complaint to the EPA alleging the EPA "unreasonably delayed action on the requested waiver. The agency has had nearly two years since CARB applied for the waiver to review the application and supporting materials and to make a decision." Complaint for Declaratory and Injunctive Relief, supra note 48 , at 4 . It further asserted that because CARB submitted application for waiver in December 2005, a reasonable time for decision had expired. Id. at 56 - 60 .

138 Complaint for Declaratory and Injunctive Relief, supra note 48 , at 8 .

139 ld. at 41.

140 Id. at $42-43$.

141 Id. at 8.

142 Letter from Attorney General of the Commonwealth of Massachusetts et al. to EPA Administrator Stephen L. Johnson, Jan. 23, 2008 (citing Mass. v. E.P.A., 127 S.Ct. at 1462). 
intend to modify the EPA's obligations under any other statute. ${ }^{143}$ As noted in Part II.B, the EPCA does not preempt legislation enacted pursuant to the California waiver. Therefore, the EISA, which was enacted under EPCA, similarly should not preempt any legislation California seeks to enact pursuant to the CAA waiver provision. As long as California meets the requirements for a waiver under the CAA, EISA's fuel economy standards should not affect the Pavley Bill.

California also argued the EPA Administrator incorrectly suggested the federal standards in the EISA affected California's waiver claim. Administrator Johnson's statement that federal standards surpassed proposed standards was plainly incorrect. ${ }^{144}$ CARB found the Pavley Bill's regulation of greenhouse gas emissions would reduce carbon dioxide emissions in California by 17.2 million metric tons by 2016 , and would result in a cumulative reduction of 33.4 million metric tons. ${ }^{145}$ In contrast, the federal standards would only achieve an 18.9 million metric ton reduction. ${ }^{146}$

\section{Probable Outcome}

Given the EPA's authority to regulate greenhouse gas emissions, ${ }^{147}$ the Ninth Circuit $^{148}$ will likely overturn EPA's denial of California's waiver request for the

143 Energy Independence and Security Act of 2007, Pub. L. No. 110-140, § 3, 121 Stat. 1492, 1498 (2007) ("Except to the extent expressly provided in this Act or an amendment made by this Act, nothing in this Act or an amendment made by this Act supersedes, limits the authority provided or responsibility conferred by, or authorizes violation of any provision of law (including a regulation), including any energy or environmental law or regulation.")

144 California Disputes EPA Claims Over Energy Laws GHG Reductions, 19 ClEAN Air REPORT 1, Jan. 10, 2008, available at 2008 WLNR 464957.

145 Id.

146 Id. Furthermore, when CARB factored in other states that adopted the Pavley Bill, the board found its standards would cumulatively achieve a more significant decrease in greenhouse gas emissions. "In assessing cumulative U.S. reductions, which includes more than a dozen other states implementing the California rules between 2009 and 2016, CARB claims its standards would achieve a 58-MMT reduction compared with a 20-MMT cumulative reduction from the federal standard. The analysis also shows California's rules would equate to a $44 \mathrm{mpg}$ CAFE standard by 2020 " compared with only 35 miles per gallon by 2020 under the federal regulations. Id.

147 See Mass. v. E.P.A., 127 S.Ct. 1438 (2007).

148 For purposes of this paper, I assume the case will ultimately be decided by the Ninth Circuit Court of Appeals. However, it should be noted that the EPA challenges the Ninth Circuit's jurisdiction. It filed a petition for review in the D.C. Circuit, citing Section 307 of the Clean Air Act, which says EPA actions with "nationwide scope or effect" must be filed in the D.C. Circuit. In response to this latest action by the EPA, California argues the letter sent by Administrator Johnson to California Governor Amold Schwarzenegger announcing an intent to deny the waiver constituted a final agency action; this letter did not suggest these rules were of nationwide scope or effect. The EPA asserts that its letter to Governor Schwarzenegger did not constitute a "final agency action" subject to judicial review. Plaintiffs Aim to Set Precedent to Review EPA Rules Outside of D.C. Circuit, 19 ClEAN AIR REPORT 7, Apr. 3, 2008. The EPA also asked the D.C. Circuit to review its denial of California's waiver request "as part of a related challenge to EPA's 'unreasonable delay' in responding to California's waiver request, in a case the litigants had agreed to dismiss the same day EPA filed the motion." EPA Pushes Novel Bid to Allow Key Panel to Review GHG Waiver Case, 29 
Pavley Bill. Given that California meets all the requirements for a preemption waiver, the Pavley Bill represents the type of innovation Congress encourages, and the EPA's precedent of granting the California waiver, the Ninth Circuit in all likelihood will - and should - find the EPA's denial arbitrary and capricious.

As long as California meets all the requirements for a waiver set out in Section 209 of the CAA, the EPA Administrator has no discretion to deny the state's request for waiver of preemption. ${ }^{149}$ The Pavley Bill fulfills these requirements and thus, the EPA improperly concluded that California did not qualify for the waiver. Although the EPA may deny a request for waiver of preemption, it can do so only in three limited circumstances, none of which exist in this situation.

First, California's determination that the Pavley Bill standards are at least as protective as federal standards was not an arbitrary or capricious finding. When California requested the waiver, no comparable federal standards existed. Thus, during the two years the petition for waiver remained pending, the EPA could not have found California's standards to be less protective than non-existent federal standards. Even at the time the EPA announced its denial of California's waiver request, California's standards remained more protective than federal standards: the Pavley Bill would reduce carbon dioxide emissions by 33.4 million metric tons compared to a federal reduction of only 18.9 million metric tons by the year $2020 .{ }^{150}$ California's finding that its standards, providing a 175 per cent greater reduction of carbon dioxide emissions over the federal regulations, are at least as protective as federal law was therefore neither arbitrary nor capricious.

In addition, the EPA improperly asserted that California did not need separate standards to meet "compelling and extraordinary conditions." . Throughout the history of CAA and California's requests for preemption waivers, both the EPA and courts have construed this term broadly. ${ }^{151}$ California has the highest human and vehicular population in the nation, unique topography highly susceptible to global warming, and some of the worst ozone concentrations in the United States. These conditions disproportionately affect the state as it must concern itself with protecting a greater number of people and with preserving a large coastline and forest areas. Furthermore, the high number of automobiles in the state results in more tailpipe emissions, and thus a higher concentration of

INSIDE THE EPA 14, Apr. 4, 2008. Califomia opposed this action, saying the "unreasonable delay case is moot because EPA has since issued its decision denying the waiver." Id. This paper does not discuss the merits of the EPA's jurisdictional challenge, but instead assumes Ninth Circuit jurisdiction. Even if the EPA wins its motion to transfer the case to the D.C. Circuit, the analysis of the merits of the case would not change. Some view the Ninth Circuit as more favorable to California, whereas the D.C. Circuit would act more favorably to the EPA; however, either circuit will probably overturn the EPA's decision for the reasons stated herein.

149 See supra, Part II.A.2.b.

1so See supra, notes $142 \cdot 44$ and accompanying text.

151 See supra, notes $62-66$ and accompanying text. 
greenhouse gases. The state, therefore, meets the required "compelling and extraordinary conditions" as the term, in the context of Section 209(b) of the CAA, has been understood for the past forty years.

Finally, Administrator Johnson could not have denied California's request for inconsistency reasons because California's standards are in line with Section 202(a) of the CAA. ${ }^{152}$ Section 202(a) encourages the reduction of any air pollutant emitted by motor vehicles, particularly when such pollution "may reasonably be anticipated to endanger public health or welfare." 153 Regulations of vehicular emissions should make use of the best technology feasible, while also taking into account the cost associated with applying such technology. ${ }^{154}$

In addition to meeting the requirements set forth in Section 209 of the CAA, the Pavley Bill represents the type of innovation Congress intended to encourage with the waiver provision. By enacting Section 209, Congress expressed a specific desire for California to develop more stringent regulations with regard to air pollution than federal regulations. The Pavley Bill addressed greenhouse gas emissions from automobile sources before the federal government, and its standards would reduce more air pollution than the federal standards enacted two years later. The Pavley Bill thus falls in line with what Congress intended California to enact through Section 209 of CAA.

Furthermore, even the EPA staff believed California deserved a preemption waiver for the Pavley Bill; when the EPA Administrator denied the request, he ignored advice from his staff. For example, Margaret Oge, head of the EPA's Office of Transportation and Air Quality, prepared a memo stating "there is no legal or technical justification for denying" California's request for a preemption waiver. ${ }^{155}$ She also "fear[ed] the credibility of the agency ... will be irreparably damaged" if the EPA denied California's waiver. ${ }^{156}$ Other internal EPA documents and reports "indicate that the overwhelming evidence compiled by the professional staff at EPA with expertise in the matter was essential ignored."157

Senator Barbara Boxer (D-Ca.) alleged Administrator Johnson "ignored the unanimous advice of his staff." 158 In fact, according to EPA internal memos,

152 Clean Air Act $\$ 202(a), 42$ U.S.C. $\$ 7521$ (2006).

153 Id. at $\S 202(\mathrm{a})(1)$.

154 Id. at $\S 202(\mathrm{a})(3)(\mathrm{A})(\mathrm{i})$ ("regulations ... shall contain standards which reflect the greatest degree of emission reduction achievable through the application of technology which the Administrator determines will be available for the model year to which such standards apply, giving appropriate consider to cost, energy, and safety factors associated with the application of such technology.").

15s EPA Memo Thickens Waiver Plot, FRESNO BEE, Feb. 28, 2008, at C4.

156 Id.

157 Id.

158 Dan Friedman, GOP Seeks Probe of Alleged Lobbying by EPA Officials, CONGRESS DAILY, Apr. 8, 2008, available at WLNR 6572000 (emphasis added). Interestingly, both United States Senators from California questioned Administrator Johnson regarding his decision to deny 
EPA Administrator Stephen Johnson denied California's waiver request despite warning from his expert staff that EPA would "likely lose the suit" if California challenged the denial. EPA officials also told the Administrator that California did, in fact, face compelling and extraordinary conditions sufficient to justify a waiver. ${ }^{159}$ Although it is unclear exactly why Administrator Johnson chose to ignore this advice, ${ }^{160}$ these internal memos suggest the entire EPA staff, aside from the Administrator, agreed that California met all requirements for a preemption waiver under the CAA. The Ninth Circuit should certainly take into account the EPA staff's widespread agreement that there was "no legal or technical justification" for the denial.

Forty years of history, dating from the time Congress enacted the CAA, also supports California's position. Prior to the Pavley Bill, the EPA always, at least partially, granted California's waiver requests. This overwhelming approval rate suggests the court should carefully scrutinize the first and only denial to determine whether the EPA's shift away from its history of liberally granting all waiver requests has any justification. EPA staff members also pointed to precedent, noting the "long history" in which EPA has granted California a waiver of preemption under CAA. ${ }^{161}$ Administrator Johnson gave no reasonable justification for his departure from precedent.

Aside from the Administrator's incorrect finding that California did not meet the requirements for a waiver, the Administrator provided additional faulty reasoning for his denial of the waiver request. He dismissed California's legislation as insufficient to provide a solution because greenhouse gases create global problems; in essence, he asserted that global problems require global solutions. ${ }^{162}$ In practice, such logic leads to absurd results. Consider a hypothetical situation where the United States wanted to reduce greenhouse gas

California's waiver request for the Pavley Bill. When Senator Diane Feinstein questioned Administrator Johnson and asked "if any top staffer recommended denial, the head of the EPA verbally ducked. 'I received hours of briefings from the technical and legal staff, with a wide range of options-legally defensible options' he said. 'You're not answering my question,' Feinstein responded. 'All I can do is believe what your non-answer means."' Frank Davies, EPA Head Ducks Senators' Grilling Over Waiver: Boxer, Feinstein Try Different Tacks, End up Equally Stymied, SAN JOSE MERCURY NEWS, Mar. 5, 2008, at 3A.

159 Barbara Boxer, Why is EPA Standing in the Way of State Law?, SACRAMENTo BeE, Jan. 27, 2008, at E5.

160 Some claim the EPA Administrator's decision was politically motivated. See, e.g., Senator Boxer Pursues GAO Investigation of EPA's Waiver Decision on Global Warming Emissions From Vehicles, U.S. FEDERAL NEWS, Feb. 8, 2008, available at 2008 WLNR 2544744 ("It was also reported on November 2 that Vice President Cheney met with auto executives who 'delivered the message that they wanted the White House to oppose California's request for a waiver under the Clean Air Act.' The EPA Administrator admitted to the Committee at our January 24 hearing that he had discussed this issue with White House officials.").

161 See, e.g., Associated Press, Internal EPA Documents Discuss California Waiver, SAN MATEO COUNTY TIMES, Feb. 27, 2008, available at 2008 WLNR 3894488.

162 See supra, notes 128 - 30 and accompanying text. 
emissions, ${ }^{163}$ but other countries had not mandated such reductions nor had any agreements to do so. ${ }^{164}$ Would the United States' proposed greenhouse gas emission reduction program have little to no impact unless all countries enact the same program? Can one dismiss the United States' proposed efforts as the futile endeavor of one country? Would the United States choose not to enact its legislation based on the reasoning that the problem can only be addressed with international cooperation? The answer to these questions is no. ${ }^{165}$ While global warming certainly requires global attention, a solution begins with the domestic legislation of individual nations.

Similarly, California can play a leading role in reducing greenhouse gas emissions even where no federal legislation exists. Certainly, a nationwide endeavor would better address global warming, but the contributions of any state can make a significant difference in the fight against global warming. A solution must start somewhere and can begin with the efforts of just one state. Furthermore, the effects of the Pavley Bill would extend beyond California, with at least fourteen other states also adopting identical regulations. ${ }^{166}$ Although the federal government now has legislation that restricts greenhouse gas emissions from automobiles, the Pavley Bill contains more stringent regulations and will therefore have a greater impact in curbing global warming.

As noted above, although the federal government should certainly be applauded for its efforts to reduce greenhouse gas emissions from vehicular sources, federal legislation does not prohibit California from enacting its own,

163 This statement is based on another California environmental bill, Assembly Bill 32, also known as the California Global Warming Solutions Act of 2006. This bill seeks to reduce greenhouse gas emissions to 2000 levels by 2010 , to 1990 levels by 2020 and to $80 \%$ below the 1990 levels by 2050. Califomia Office of the Governor, Fact Sheet: Landmark Global Warming Legislation, http://gov.ca.gov/index. php?/fact-sheet/4445/ (last visited Nov. 20, 2008).

164 A situation where the United States is eager to enact environmental legislation, which requires international support and cooperation seems unlikely, however, given it is the only developed nation which has not ratified the Kyoto Protocol. Ratifying the Kyoto Protocol essentially commits a nation to reducing greenhouse gas emissions or to engage in emissions trading. Despite the United States' status as the world's top polluter, it has not expressed the intention to ratify the Kyoto Protocol anytime soon. See Jorge Chapa, Australia Ratifies the Kyoto Protocoll, INHABITAT, Dec. 5, 2007, http://www.inhabitat.com/2007/12/05/australia-ratifies-the-kyotoprotocol/ (last visited Nov. 20, 2008).

165 If all countries take the position of the EPA Administrator, environmental problems would worsen as states would not enact national global warming legislation unless it could take international effect. A nation could argue that since global problems require global support, efforts of individual states would be futile. Such reasoning would prevent nations that do want to reduce greenhouse gases from protecting the environment. Nations that choose to enact global warming legislation should do so regardless of whether other countries have created similar environmental legislation. While it may be true that global warming threats are best addressed through international resolutions, nations can still try to solve these problems through legislation at a domestic level prior to engaging in any cooperative efforts with other countries. Each nation can independently contribute to achieving solutions to the problem of global warming regardless of the actions of other countries.

166 See supra note 103 and accompanying text. 
more stringent, regulations under the CAA. Allowing both federal and state legislation to coexist reflects the commitment to cooperative federalism Congress envisioned for the CAA and other environmental statutes. This modified and cooperative federalism model created by CAA has worked well for the past forty years; it has allowed other states that are most threatened by environmental problems the opportunity to enact more stringent requirements that have often then been adopted by Congress. The EPA therefore should not limit California's innovations. Given Congress' express approval of California's innovation and the fact that all efforts to reduce greenhouse gases may curb global warming's detrimental effects, the Ninth Circuit should overturn the EPA's denial of California's waiver request.

\section{CONCLUSION}

Federal legislation and state innovation are both necessary to best combat environmental problems. Cooperative federalism in this field provides a base level of regulation while also allowing states to test more stringent requirements. Innovation and experimentation best solve problems created by global warming since the federal approach can often learn from a state's model or adopt state legislation that has proven both feasible and successful. The EPA's denial of California's waiver request for the Pavley Bill prevents such cooperative federalism and should be overturned.

Even if the Ninth Circuit upholds the EPA's decision, or perhaps even before a court can rule on California's petition for review, Congress may overturn Administrator Johnson's ruling by statute. ${ }^{167}$ A number of bills introduced in both houses of Congress would either require the EPA to review its denial or grant California a preemption waiver. For example, Senators Feinstein (D-CA) and Snowe (R-ME) introduced the Greenhouse Gas Endangerment Finding Deadline and California Waiver Reconsideration Act ${ }^{168}$ to direct the EPA Administrator to reconsider its denial by no later than June 30, 2009. ${ }^{169}$ Similarly, Representatives Welch (D-VT) and Sherman (D-CA) co-sponsored the Right to Clean Vehicles Act ${ }^{170}$ which would outright grant California's CAA waiver request. ${ }^{171}$ Either of these bills could overturn the EPA's denial and allow California - as well as other states - to enact the Pavley Bill.

167 Senator Boxer (D-CA) also expressed the expectation that "the next president would overtum the EPA decision because Democrats Barack Obama and Hillary Clinton and Republican John McCain support California's waiver request." Frank Davies, Internal EPA Documents Discuss California Waiver, SAN MATEO COUNTY TIMES, Feb. 27, 2008, available at 2008 WLNR 3894488.

168 S. 2806, 110 th Cong. (2008).

169 Plaintiffs Open to EPA Pact Over Schedule for GHG Risk Finding, 29 INSIDE THE EPA, Apr. 4, 2008, available at 2008 WLNR 6343984

170 H.R. 5560, 110th Cong. (2008).

17 New House Bill Seeks to Overturn EPA Decision on California Auto Standards Waiver, CONG. DOCUMENTS, Mar. 6, 2008. 
Regardless of the form in which California (hopefully) obtains its preemption waiver for the Pavley Bill, the state should continue to take advantage of Section 209 of CAA. Since the enactment of CAA, California's standards have often been adopted by other states and, at times, by the federal government. The California waiver created a number of popular pieces of environmental legislation and has generally reflected a successful model of cooperative federalism. As such, allowing California to continue experimenting with new ideas is of vital importance to achieving national, and global, emissions reduction goals. 
